\title{
Association between Rainy Season and Diarrhea in 13- to 24-Month-Old Toddlers
}

\author{
Jeceline Sutarto, ${ }^{1}$ Edward Surjono ${ }^{2}$ \\ ${ }^{1}$ Faculty of Medicine and Health Sciences Atma Jaya Catholic University, Jakarta, Indonesia, \\ ${ }^{2}$ Department of Pediatrics, Faculty of Medicine and Health Sciences Atma Jaya Catholic University, \\ Jakarta, Indonesia
}

\begin{abstract}
Diarrhea is the second leading cause of death in children under five year and is considered a prevailing problem in many developing countries, including in Indonesia. Diarrhea is a multifactorial disease and season is suggested as one of the attributing factors of this disease. This study aimed to identify the association between the rainy season and diarrhea in 13- to 24-month-old toddlers. This was a cross-sectional analytical observational study on medical records of 13- to 24-month-old-toddlers with infectious diarrhea who visited Penjaringan I Sub-district Public Health Center, North Jakarta, Indonesia from 2016 to 2019 that included three cycles of the rainy and dry seasons. Data collection was performed in March 2020 and 286 medical records were included in the study. The relationship between the independent and dependent variables was analyzed using chi-square. Of the total cases, 83 cases occurred in rainy season and 203 cases occurred in dry season $(p=0.291)$. Diarrhea was seen in girls aged13-16 months. There is no significant association between rainy season and diarrhea.
\end{abstract}

Keywords: Diarrhea, rain, season

\section{Hubungan antara Musim Hujan dan Kejadian Diare pada Balita Usia 13-24 Bulan}

\begin{abstract}
Abstrak
Diare merupakan penyebab kematian balita nomor dua di dunia yang masih menjadi masalah pada banyak negara berkembang, termasuk Indonesia. Diare adalah sebuah penyakit multifaktorial. Musim merupakan salah satu faktor yang mempengaruhi diare melalui dampaknya pada lingkungan. Penelitian ini bertujuan mengetahui hubungan antara musim hujan dan kejadian diare pada balita usia 13-24 bulan. Penelitian ini merupakan penelitian analitik observasional dengan metode potong lintang. Pengumpulan data dilakukan pada bulan Maret 2020 di Puskesmas Kelurahan Penjaringan I, Jakarta Utara, dengan menggunakan rekam medis periode tahun 2016-2019, yang meliputi masing-masing tiga siklus musim hujan dan musim kemarau. Sampel penelitian adalah usia 13-24 bulan yang didiagnosis dengan diare infeksi. Hubungan antara variabel independen dan dependen diuji menggunakan chi-square. Dari 286 rekam medis yang digunakan, 83 kasus terjadi sewaktu musim hujan dan 203 kasus terjadi sewaktu musim kemarau ( $\mathrm{p}=0,291)$. Kejadian diare paling tinggi pada perempuan kelompok usia 13-16 bulan. Tidak terdapat hubungan bermakna antara musim hujan dengan kejadian diare.
\end{abstract}

Kata kunci: Diare, hujan, musim

Corresponding Author: Edward Surjono, Department of Pediatrics, Faculty of Medicine and Health Sciences Atma Jaya Catholic University, Jakarta, Indonesia. Email: edward.surjono@atmajaya.ac.id 


\section{Introduction}

Global climate change will increase the risk of diarrhea through extreme weather events due to the nature of this disease that is sensitive to climate change. Diarrhea is the second leading cause of death in children under five years of age and a prevailing problem in many developing countries. ${ }^{1}$ Diarrhea disease was responsible for approximately 533.768 deaths in under five in 2017. ${ }^{2}$ In Indonesia, diarrhea is an endemic disease with the potentials of becoming an outbreak. $^{3}$

Diarrhea is a multifactorial disease, where the factors can generally be classified into four main categories: maternal, child, environment, and socioeconomic., ${ }^{2,3} \mathrm{~A}$ study by Troeger et al. $^{2}$ and Adisasmito ${ }^{3}$ found that among the aforementioned four factors, the environmental factor has the biggest influence on diarrheal disease. The availability of clean water, followed by proper latrine, play the most crucial roles in reducing the number of diarrhea cases. ${ }^{2,3}$

Diarrheal disease peaks at the beginning of the rainy season, during the transition from the dry season, where rainfall remains low and there is a temperature change. ${ }^{4}$ Previous studies have shown an increment in the number of diarrhea cases during the rainy season., ${ }^{5,6,7}$ Seasonal change indirectly affects diarrhea through the environment, for instance, when heavy rainfall contaminates surface water by sweeping sediments and dirt to the surface. ${ }^{8}$

In Penjaringan, Jakarta, Indonesia, during the rainy season when the water supply is abundant, some areas that have wells are able to utilize them in addition to the state's owned piped water supply service (air PAM). ${ }^{9}$ During the dry season, with the fluctuating debit of water, vendors selling tap water stored in gallons (air ledeng pikulan) becomes the sole supplier of clean water for the area. ${ }^{9,10}$ This becomes an issue as some households in Penjaringan area still utilize tap water originated from surface water, as a drinking water source. Despite treatment efforts such as boiling, contamination has never been successfully eradicated from the horrendously contaminated water sources in Penjaringan. ${ }^{11}$

Diarrhea is an endemic disease in Indonesia with a high mortality rate in under-five children. Environmental factor, which is indirectly affected by seasonal changes, is the most significant factor affecting diarrheal disease. Not much has been explored regarding the association between seasons and pediatric diarrheal disease in metropolitan areas of Indonesia. It is necessary to anticipate diarrheal disease by understanding its pattern during a given time for future anticipations. This study aimed to identify the association between rainy season and diarrhea among children aged 13-24 months visiting the Penjaringan I Sub-district Public Health Center, North Jakarta, Indonesia.

\section{Methods}

This was a cross-sectional analytical observational study using secondary data from the diarrhea patient medical records at Penjaringan I Sub-district Public Health Center, North Jakarta, in March 2020. For the season data, data were obtained from the Indonesian Agency for Meteorology, Climatology, and Geophysics (Badan Meteorologi, Klimatologi, dan Geofisika/ BMKG) to be used to determine periods of the rainy season and dry season. The dependent variable was the number of diarrhea cases, while the independent variable was the duration of the dry season and rainy season according to BMKG. This study used three cycles of the rainy season and three cycles of the dry season during the period of 2016-2019 which, according to BMKG, between October 21, 2016 and November 30, 2019. BMKG defines rainy season as the season when the rainfall in a period of 10 days equals to or exceeds $50 \mathrm{~mm}$, followed by another 10-day period. ${ }^{12}$

This study used medical records with the following inclusion criteria: (1) diarrhea patient aged between 13 and 24 months old by the time of diagnosis, (2) Good nutritional status (Z score for WHO's length/height-for-age curve not less than -2 or no stunting), (3) Case reported between October 21, 2016 and November 30, 2019. Records were excluded if (1) Patient was not between 13 and 24 months old by the time of diagnosis, (2) patient had poor nutritional status (Z score for WHO's length/height-for-age curve less than -2 or stunted), (3) patient has digestion problems causing non-infectious diarrhea such as lactose intolerance or cow's milk allergy, (4) Other primary diseases with diarrhea as the manifestation, and (5) case was not reported between October 21, 2016 and November 30, 2019. The sample meeting the inclusion criteria were then categorized based on the date of diagnosis into the corresponding season and year.

The minimum sample size as calculated using the total sampling method was 32 samples. Data collected were then processed using the IBM SPSS 
Table 1 Subject Demographics

\begin{tabular}{lcc}
\hline \multicolumn{1}{c}{ Parameter } & $\mathbf{n}$ & $\mathbf{\%}$ \\
\hline Age & & \\
13-16 months & 133 & 46.5 \\
17-20 months & 95 & 33.2 \\
$\quad$ 21-24 months & 58 & 20.3 \\
Sex & & \\
$\quad$ Male & 129 & 45.1 \\
$\quad$ Female & 157 & 54.9 \\
\hline
\end{tabular}

version 23. A univariate analysis was performed to obtain the frequency and proportion of the study population. A bivariate analysis was performed to analyze the association between the rainy season and diarrhea using chi-square $(p<0,05)$. A normality test for the distribution of data was not performed as the data were nominal, where the data were only classified into either rainy season or dry season based on the date of diagnosis. Ethical clearance from the ethical committee of Atma Jaya Catholic University (No.
04/02/KEP-FKUAJ/2020) had been given prior to the commencement of the study.

\section{Results}

There were 286 medical records fulfilling the inclusion criteria. Table 1 shows that the majority of patients suffering from diarrhea were within the age group of $13-16$ months (46.5\%), followed by age group 17-20 months (33.2\%), and $21-24$ months $(20.3 \%)$. There were more girls $(54.9 \%)$ than boys (45.1\%).

Figure 1 shows the distribution of diarrhea cases from 2016-2019 by month. There were two months with the highest number of cases, i.e. October and July, with 39 cases in each respective month. The number of diarrhea case was lowest in May with only 9 cases.

Table 2 shows the number of diarrhea cases as categorized according to season and year. It shows that the number of cases during the dry season was always higher than in the rainy season in any given year. The total number of

Table 2 Diarrhea Case and Respective Season of Occurrence

\begin{tabular}{lccccc}
\hline \multirow{2}{*}{ Year } & \multicolumn{5}{c}{ Season } \\
\cline { 2 - 5 } & \multicolumn{2}{c}{ Rainy Season } & \multicolumn{2}{c}{ Dry Season } & \multirow{2}{*}{ p-value } \\
\cline { 2 - 5 } & $(\mathrm{n}=83)$ & $\%$ & $(\mathrm{n}=203)$ & $\%$ & \\
\hline $2016-2017$ & 8 & 22.9 & 27 & 77.1 & \multirow{2}{*}{0.291} \\
$2017-2018$ & 27 & 25.5 & 79 & 74.5 & \\
$2018-2019$ & 48 & 33.1 & 97 & 66.9 & \\
\hline
\end{tabular}

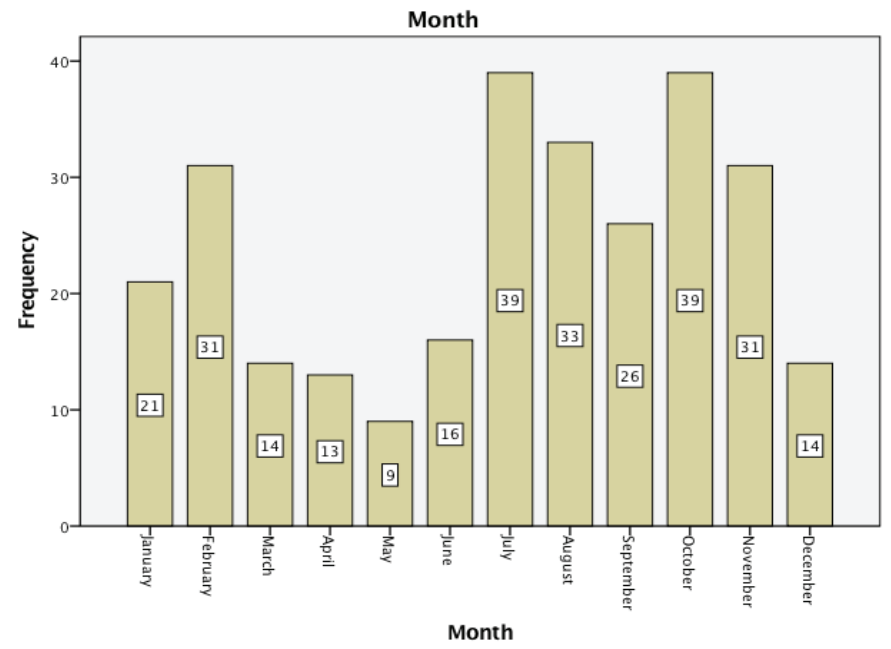

Figure Distribution of Cases by Month 
cases during the rainy season was 83 (29\%), while the number of cases during the dry season was 203 (71\%). The chi-square test showed no significant correlation between both variables $(\mathrm{p}>0.05)$.

\section{Discussion}

Diarrheal disease is most prevalent in children under the age of two, notably between the age of 12 and 23 months according to Moon et al.. ${ }^{13}$ Diarrhea case is particularly high between the age of 12 and 23 months because the maternal antibodies have started declining since birth. However, the immune system starts developing after the age of two from repeated environmental exposures. It is also the time where a child is able to walk independently and is, therefore, prone to picking contaminated objects from the environment. ${ }^{4}$

Some studies found that boys are more likely to get diarrhea than girls as they do more environmental activities. ${ }^{4,13}$ This is contradictory to what was found in this study. This study supports studies by Yusuf ${ }^{14}$ and Anyorikeya ${ }^{6}$ that also found more female diarrhea patients than males. According to Yusuf, gender is not a predisposing factor of diarrheal disease. ${ }^{14}$

Different countries have different peaks of diarrheal disease. ${ }^{1}$ Rotavirus diarrhea in tropical countries is reported throughout the year, with a peak in the transition period from dry season to rainy season. ${ }^{4}$ Zhou et al. ${ }^{15}$ in China found an increase in diarrhea cases during the dry season because vectors such as planktons that carry rotavirus and other pathogenic bacteria were found to proliferate better in warmer water.Aik et al. in their study conducted in Indonesia's neighboring tropic country, Singapore, found three annual peaks of diarrheal disease, occurring between July and August. ${ }^{1}$ The studies of Creek at al. ${ }^{5}$ in Botswana, Anyorikeya et al. ${ }^{6}$ in Ghana, and Bucardo et al. ${ }^{7}$ in Nicaragua all found that diarrhea cases were higher during the rainy season. This study found two peaks of diarrheal disease, which were in the month of July and October, although cumulatively, the number of cases was higher in the summer months. It is in accordance with Cahyorini and Anwar's finding in Bali, who also found two peaks of diarrheal disease in a year, which were in the middle of the year when rainfall was lowest, and at the end of the year when rainfall was highest. ${ }^{16}$

The school holiday is partially responsible for the rocketing number of diarrhea cases during the dry season, particularly in July. School holiday in Indonesia lasts from June to July, with some even extending to August. In the year 20162019, the Eid holiday coincidentally fell during the school holiday. It is a deep-rooted tradition in Indonesia for those celebrating Eid to travel back to their hometown (mudik) during the holiday. Outbound travel reduces the number of children at risk of locally acquired diarrheal diseases, but may also increase the risk of traveler's diarrhea, depending on the destinations and food choices. Due to the nature of acute infectious diarrhea, parents are more likely to seek medical attention at their travel destination first or self-medicate rather than delay medical assistance until they return home. ${ }^{1}$

The dry season is also associated with drought in Indonesia. During the mid of summer where water shortage occurs, the population would have to rely on surface water, which most likely is contaminated..$^{9}$ Boithias et al. in Luang Prabang found that surface water has low turbidities, giving an illusion that the water is safe to consume even when it is not. Most of Luang Prabang's population had used bottled water as drinking water but still relied on surface water for domestic activities such as showering or washing fruits and vegetables. ${ }^{17}$ This condition mirrors how water is utilized in the sub-district of Penjaringan, North Jakarta, where this study was conducted.

Penjaringan area is a low-lying and floodprone area given to its coastal location, but it, too, is not immune from water shortage during the dry season, especially given its majority of the low-income population. ${ }^{10,11,18}$ Jakarta experiences problems related to water throughout the year; with flood occurring during the rainy season and drought during the dry season. In 2010, it was found that the state's owned piped water supply service (air PAM) was only able to supply $44 \%$ of Jakarta's population. ${ }^{10}$ The Central Bureau of Statistics for Penjaringan in 2018 found that 32,5\% of the population still relied on tap water (air ledeng), which came from surface water or groundwater, due to inadequate supply or inability to afford bottled water or PAM, which cost a lot more than tap water. ${ }^{9}$ This was problematic as the surface water, namely the thirteen rivers crossing over Jakarta, were all heavily contaminated. ${ }^{10}$

Due to its coastal location, the groundwater in Penjaringan is horridly contaminated with salt and deemed unsuitable for consumption, making surface water the sole source for tap water (air ledeng). ${ }^{9}$ Komarulzaman et al. further found that 
$18 \%$ of Indonesian households still relied on direct, untreated, surface water as a source of drinking water, and only $11 \%$ had access to tap water, albeit the fluctuating flow during the dry season and pipe contamination..$^{19}$ In the time of flood, water is abundant, but there too is a higher risk of water-borne diseases such as diarrhea due to contaminated or spoiled water storage. ${ }^{18}$

Another reason for the contrasting number of cases during the rainy season compared to the dry season was due to the length of each season. According to BMKG's calculation for the year 2016-2019, the dry season lasted roughly eight months, meaning the rainy season only lasted roughly four months. ${ }^{12}$ The ever-increasing length of dry season was supported by Jiang et al. on their study in the Congo Rainforest from 1988-2013, who found an increase in dry season length by as many as 6.4-10.4 days/decade, with dry season starting earlier or ending later every year, as a direct effect of global warming. ${ }^{20}$

This study focused on how seasonal change affects the environment to cause diarrhea, although diarrhea is also influenced by other factors, namely maternal, child, and social and economic factors. Maternal factor includes mother's knowledge and attitude towards clean and healthy living behavior, education level, and occupation. Child factor includes nutritional status, feeding status (ASI), and immunization completion. Social and economic factors include the number of children in the household, paternal education and occupation, income, and the number of family members. Environmental factor includes the provision of clean water, latrines, and waste disposal. ${ }^{3}$

The first limitation of this study was the incomplete data collection due to Jakarta's large-scale social restrictions as a response to COVID-19. Second, data for length and weight were available, but the record of prematurity or low birth weight was never stated, making nutritional status assessment less accurate. Third, incompletion of other data such as breastfeeding (ASI) information or immunization completion, making it impossible to assess other factors attributing to diarrhea. Fourth, data regarding the etiology of the pathogen were not stated in the medical record, making it impossible to investigate further regarding the causative pathogens. Should this study be developed further, it is suggested that the cohort method is applied, with adjustments to the rainy season and dry season calculations of BMKG in the upcoming years, and taking into account the other three factors contributing to diarrhea in addition to the etiologic pathogen whenever possible.

In conclusion, the diarrheal disease in Penjaringan I Sub-district Public Health Center for the year 2016-2019 mostly affected females aged 13-16 months. There were two peaks of diarrheal disease; in July during the mid of summer and in October during the transition from dry to rainy season, but the overall number of cases was higher during the dry season. Statistical analysis showed no significant correlation between the rainy season and diarrheal disease.

\section{References}

1. Aik J, Ong J, Ng LC. The effects of climate variability and seasonal influence on diarrhoeal disease in the tropical city-state of Singapore-A time-series analysis. Int J Hyg Environ Health. 2020;227:113517.

2. GBD 2017 Diarrhoeal Disease Collaborators. Quantifying risks and interventions that have affected the burden of diarrhoea among children younger than 5 years: an analysis of the Global Burden of Disease Study 2017. Lancet Infect Dis. 2020;20(1):37-59.

3. Adisasmito W. Diarrhea risk factors of infant and children under five years in indonesia: a systematic review of public health academic studies. Makara Journal of Health Research. 2007;11(1):1-10.

4. Rifai R, Wahab A, Prabandari YS. Kebiasaan cuci tangan ibu dan kejadian diare anak: studi di Kutai Kartanegara. Berita Kedokteran Masyarakat. 2016;32(11):409-14.

5. Creek TL, Kim A, Lu L, Bowen A, Masunge J, Arvelo W, et al. Hospitalization and mortality among primarily nonbreastfed children during a large outbreak of diarrhea and malnutrition in Botswana, 2006. J Acquir Immune Defic Syndr. 2010;53(1):14-9.

6. Anyorikeya M, Ameme DK, Nyarko KM, Sackey SO, Afari E. Trends of diarrhoeal diseases in children under five years in the War Memorial Hospital-Navrongo, Ghana: 2010-2013. Pan Afr Med J. 2016;25(Suppl 1):8.

7. Bucardo F, Reyes Y, Becker-Dreps S, Bowman $\mathrm{N}$, Gruber JF, Vinjé J, et al. Pediatric norovirus GII.4 infections in Nicaragua, 1999-2015. Infect Genet Evol. 2017;55:305-12.

8. Mukabutera A, Thomson D, Murray M, Basinga P, Nyirazinyonye L, Atwood S, et al. Rainfall variation and child health: effect of 
rainfall on diarrhea among under 5 children in Rwanda, 2010. BMC Public Health. 2016;16(1):731.

9. Badan Pusat Statistik Kota Administrasi Jakarta Utara. Kecamatan Penjaringan dalam Angka, 2018. Jakarta: BPS Kota Administrasi Jakarta Utara; 2018.

10. Harsoyo B. Teknik pemanenan air hujan (rain water harvesting) sebagai alternatif upaya penyelamatan sumberdaya air di wilayah DKI Jakarta. Jurnal Sains \& Teknologi Modifikasi Cuaca. 2010;11(2):29-39.

11. Kooy M, Walter CT. Towards a situated urban political ecology analysis of packaged drinking water supply. Water. 2019;11(2):225.

12. BMKG. Prakiraan Musim Hujan Tahun 2019/2020 di Indonesia. [cited 2019 Sept 13]. Available from: ?p=prakiraanmusim-hujan-tahun-2019-2020-diindonesia\&lang=ID\&tag=

13. Moon J, Choi JW, Oh J, Kim K. Risk factors of diarrhea of children under five in Malawi: based on Malawi Demographic and Health Survey 2015-2016. J Glob Health Sci. 2019;1(2):e45.

14. Yusuf S. Profil diare di ruang rawat inap anak. Sari Pediatri. 2011;13(4):265.

15. Zhou X, Zhou Y, Chen R, Ma W, Deng H, Kan
H. High temperature as a risk factor for infectious diarrhea in Shanghai, China. J Epidemiol. 2013;23(6):418-23.

16. Cahyorini C, Anwar A. Hubungan variabilitas iklim (curah hujan, suhu, dan kelembaban) dengan kejadian diare di kota Denpasar, Provinsi Bali. Jurnal Ekologi Kesehatan. 2016;15(3):167-78.

17. Boithias L, Choisy M, Souliyaseng N, Jourdren M, Quet F, Buisson Y, et al. Hydrological regime and water shortage as drivers of the seasonal incidence of diarrheal diseases in a tropical montane environment. PLoS Negl Trop Dis. 2016;10(12):e0005195.

18. Pooroe V, Prabaharyaka I. Preventive strategy in response to climate change and infrastructural failures for Jakarta slum dwellers. Drink Water Eng Sci Discuss. 2012; 5(1):421-34.

19. Komarulzaman A, Smits J, de Jong E. Clean water, sanitation and diarrhoea in Indonesia: Effects of household and community factors. Glob Public Health. 2017;12(9):1141-55.

20. Jiang Y, Zhou L, Tucker CJ, Raghavendra A, Hua W, Liu YY, et al. Widespread increase of boreal summer dry season length over the Congo Rainforest. Nat Clim Chang. 2019;9(8):617-22. 